\title{
Rapid Assessment Method of Flood Damage Using Spatial-Statistical Models
}

\author{
Abdul Hamid Mar $\operatorname{Iman}^{1} \&$ Edlic Sathiamurthy ${ }^{2}$ \\ ${ }^{1}$ Sustainable Environment and Conservation Cluster, Faculty of Agro-Based Industry, Universiti Malaysia \\ Kelantan, Malaysia \\ ${ }^{2}$ School of Marine Science and Environment, Universiti Malaysia Terengganu, Kuala Terengganu,Terengganu, \\ Malaysia \\ Correspondence: Abdul Hamid Mar Iman, Sustainable Environment and Conservation Cluster, Faculty of \\ Agro-Based Industry, Universiti Malaysia Kelantan, 17600 Jeli, Kelantan, Malaysia. E-mail: \\ hamid.m@umk.edu.my; edlic@umt.edu.my
}

Received: July 25, 2016

Accepted: August 25, 2016

Online Published: December 3, 2016

doi:10.5539/jgg.v8n4p46

URL: http://dx.doi.org/10.5539/jgg.v8n4p46

\begin{abstract}
Attention to damage assessment is always a priority especially in cases of natural disaster. The state of Kelantan is known to be one of a few Malaysian states with noticeable natural disaster, in particular, flood. In December 2014, an extraordinary magnitude of flood - nicknamed as yellow flood - struck the state causing hundreds of million ringgit of damage to properties. The purpose of this study is to demonstrate a spatial approach to estimating property damage incurred by flood. By selecting a badly affected area, GIS was used to map geo-referenced flood-hit location in Kuala Krai, Kelantan. Flood hazard was modelled and superimposed on estimated property damage. GIS spatial technique was then employed to estimate the flood damage incurred. This study, however, did not make a complete damage assessment of the properties but rather focusing on the methodology of damage assessment to show how it can be implemented. In conclusion, GIS spatial technique can generally be used to provide flood damage rapid assessment method.
\end{abstract}

Keywords: damage assessment, natural disaster, flood, property damage

\section{Introduction}

The December 2014's flood has caused huge damage of close to RM 1 billion to the country, exclusive of RM 78 million for cleaning operations in Kelantan. A report quoted that about RM 200 million was estimated for the damage of infrastructure in Kelantan (The Star, 2/2/2015). According to Urban Wellbeing, Housing and Local Government Minister, Datuk Rahman Dahlan, between 2,000 and 3,000 houses in Kelantan were destroyed in the worst flood ever in decades (Azura, 2015). More than 200,000 victims were affected by the massive flood which claimed 21 lives (Anon, 2015).

One of the main concerns of flood is to estimate the extent of damage to properties and other assets. It is an intricate task to perform since damage assessment needs itemized identification and estimate of affected objects. Some studies resort to only assessing flood impact without being able to provide the monetary estimate of the damage (see for e.g. Ab-Jalil and Aminuddin, 2006; Pradan, 2009). Therefore, it is vitally important to devise a rapid assessment method that can provide a reliable method for estimating the monetary loss as soon as flood strikes in a particular location. Flood damage assessment itself is not a new thing; there has been a substantial body of literature dealing with it. However, the techniques are difficult to generalize since they vary and case-to-case.

By applying empirical damage or loss functions meant for compensation, relief, and/or insurance purposes, flood damage rapid assessment method (FD-RAM) seeks to estimate the expected monetary damage as soon as a disaster strikes (Poser and Dransch, 2010). In case of flood, these models calculate the expected damage as a function of inundation depth, building characteristics, and possibly further parameters such as water contamination (Poser and Dransch, 2010). 


\section{Theoretical Background}

\subsection{Flood Damage Model}

For any property, expected physical damage (EPD) is generally modelled as:

$$
\mathrm{EPD}=\mathrm{f}(\mathrm{SD}, \mathrm{CD})
$$

where SD is structural damage and CD is content damage. SD comprises damage to land/soil and building while $\mathrm{CD}$ can refer to any type and/or amount of 'content' asset. Therefore, 'content' can comprise any moveable asset inside or outside a building such furniture, radio, television, appliance, vehicle, clothes, money, etc. Damage to land/soil is difficult to ascertain. For example, the eroded soil of a land parcel may need to be replaced. Consequently, it incurs re-fill cost. However, the amount of nutrients that is being washed away from a farm as well as re-fill cost are difficult to measure. In the same manner, the number of trees/crop damaged by flood is not easy to quantify.

To overcome the above difficulty, a survey based approach is proposed adopting the model as shown in equation (1). A sample survey needs to be conducted to collect data on the quantum of damage of each property or item at a particular site. For landed properties such as residential, office, and commercial, structural as well as content damages are taken as some percentages of property value. In general, equation (1) can be re-expressed as:

$$
\mathrm{EPD}=\mathrm{SD}+\mathrm{CD}=(. \mathrm{p} 1 * \mathrm{ALV}+. \mathrm{p} 2 * \mathrm{ABV})+. \mathrm{p} 3 *(\mathrm{ALV}+\mathrm{ABV})
$$

where $\mathrm{ALV}=$ assessed land value; $\mathrm{ABV}=$ assessed building value; .p1, .p2, and .p3 = certain defined "proportion" or "percentage" property component's damage in decimal form. ALV, ABV, and any other 'content' asset can be estimated by replacement cost approach. Alternatively, market value (MV) of property can be used in place of ALV and ABV if sales data are available.

For agricultural properties, damage can occur to land/soil (structure) and tree/crop (content). Again, it is difficult to ascertain damage to these elements. For compensation purposes, land/soil damage can be estimated as a percentage of market value of a particular type of agricultural property but tree/crop damage is much more difficult to estimate. The general formula for damage estimation of agricultural properties with immature trees/crop is modified from equation (2) as follows:

$$
\mathrm{EPD}=\mathrm{SD}+\mathrm{CD}=\text { land } / \text { soil }+ \text { tree } / \mathrm{crop}=. \mathrm{q} 1 * \mathrm{MV}+\mathrm{n}\left[(\mathrm{c}-\mathrm{d})(1+\mathrm{i})^{\mathrm{t}}\right]
$$

where MV = market value of a particular type of agricultural property (alternatively, actual replacement cost can be used); .q1 = a defined proportion in decimal form; $\mathrm{c}=$ cost of replacement new of the tree/crop; $\mathrm{i}=$ discounting rate; $\mathrm{t}=$ age of immature crop; $\mathrm{n}=$ number of damage trees/crop.

However, this formula cannot be used directly without modification based on the type of agricultural property under view. For example, damage to annual and perennial crop such as banana, maize, rubber, oil palm, cocoa, and orchard trees need to be estimated by "individual" tree counting - a daunting, if not impossible, task in FD-RAM. As another example, the immaturity period is different for different crops. For instance, the immature period for oil palm is four years, rubber five years, while for some orchard trees, this period may be up to seven years.

A sample survey in the disaster area is needed in order to compute the reasonable figures of all the above damage components. Specifically, a priori information is needed to compute .p1, .p2, and .p3.

\subsection{Rapid Damage Assessment Procedure}

The whole procedure of rapid assessment of flood damage is part of the general concept of decision support system promoted by Malczewski (1997). Ideally, it should become part of national disaster management programs of any country troubled by the disaster. The actual implementation of flood damage rapid assessment method is rather complex. It has two main components, namely mapping component and spatial modelling component.

The mapping component has the following mapping activities: boundary of study area; and distribution of poor population; sampling points to compute asset value, particularly building and land value. Geographic Information System (GIS) is a standard method for flood mapping through various kinds of software such as ArcGIS, MapInfo, Idrisi, etc. One of the most widely used GIS software is Environmental System Research Institute's (ESRI) ArcGIS 10.x.

The spatial modelling process has the following modelling activities: flood inundation coverage/flood modelling based on rainfall-runoff method; spatial flood damage-estimating model; and general damage estimate. Fundamentally, we can specify flood damage-estimating model in a number of ways (Messner et al., 2007; Merz 
et al., 2010; Green et al., 2011). Factors such as flood depth, velocity, duration, water contamination, precaution, and warning time can be included. However, inclusion of flood factors cannot be generalized and is very much determined by data availability.

One potential spatial flood damage-estimating model is Geographically Weighted Regression (GWR) originally developed by Fotheringham et al. $(2000 ; 2002 ; 2005)$. Suppose we had some location in the study area, perhaps one of the data points, where $(\mathrm{x}, \mathrm{y})$ are the coordinates of its position. We can rewrite the model, in vector form as:

$$
\mathrm{V}(\mathrm{x}, \mathrm{y}) \mathrm{W}=\mathrm{W}(\mathrm{x}, \mathrm{y}) \mathrm{a}+\mathrm{W}(\mathrm{x}, \mathrm{y}) \mathrm{Z}+\mathrm{W}(\mathrm{x}, \mathrm{y}) \mathrm{e}
$$

where $V$ is value of damage, $a$ is regression's intercept, $Z$ represents hydrological, physical, environmental, and socio-economic variables/factors, $\mathrm{W}$ is spatial weight matrix, $e$ is error term, and is some measure of spatial component of data points. This relationship is fitted by least squares to give an estimate of the parameters at the location $(x, y)$ and a predicted value. This is achieved through the implementation of the geographical weighting scheme. The weighting scheme is organized such that data nearer $(\mathrm{x}, \mathrm{y})$ is given a heavier weight in the model than data further away.

Using OLS, the parameters for a linear regression model is obtained by solving:

$$
\beta=\left(Z^{\mathrm{T}} \mathrm{Z}\right)^{-1} \mathrm{Z}^{\mathrm{T}} \mathrm{V}
$$

The parameter estimates for GWR are solved using a weighting scheme:

$$
\beta(\mathrm{g})=\left(\mathrm{Z}^{\mathrm{T}} \mathrm{W}(\mathrm{g}) \mathrm{X}\right)^{-1} \mathrm{Z}^{\mathrm{T}} \mathrm{W}(\mathrm{g}) \mathrm{V}
$$

The weights are chosen such that those observations near the point in space where the parameter estimates are desired have more influence on the result than observations further away. Two functions we have used for the weight calculation have been (a) bi-square and (b) Gaussian. In the case of the Gaussian scheme, the weight for the $i_{t h}$ observation is:

$$
\mathrm{w}_{\mathrm{i}}(\mathrm{g})=\exp (-\mathrm{d} / \mathrm{h})^{2}
$$

where $d$ is the Euclidean distance between the location of observation $i$ and location $g$, and $h$ is a quantity known as the bandwidth. (There are similarities between GWR and kernel regression). One characteristic that is not immediately obvious, is that the locations at which parameters are estimated need not be the ones at which the data have been collected.

The resulting parameter estimates are mapped in order to examine local variations in the parameter estimates. One might also map the standard errors of the parameters estimates as well. Hypothesis tests are possible - for example one might wish to test whether or not the variations in the values of a parameter in the study area are due to chance. The bandwidth may be either supplied by the user, or estimated using a technique such as cross validation technique. The $(\mathrm{x}, \mathrm{y}) \mathrm{s}$ are typically the locations at which data are collected. This allows a separate estimate of the parameters to be made at each data point. The resulting parameter estimates can them be mapped.

Flood Loss Estimation Model for the private sector (FLEMOps) on the meso scale (Thieken et al., 2008) is applied with some adaptation to the location situations. This model calculates the damage ratio for residential buildings as a function of inundation depth classified into five classes and building characteristics, i.e. three buildings types and two building qualities. To be applicable on the meso scale, mean building composition and the mean building quality per municipality were derived and the resulting damage ratios are multiplied by total asset values disaggregated to land use units (Thieken et al., 2005).

Spatially assessed flood damage by kriging technique is used in performing data analysis. A modified Ordinary Least Squares technique, kriging adopts weights to the surrounding measured values to derive a prediction for an unmeasured location. The general formula for both interpolators is formed as a weighted sum of the data:

$$
\hat{Z}_{\left(S_{0}\right)}=\sum_{i=1}^{N} \lambda_{i} Z\left(S_{i}\right)
$$

where $Z_{\left(S_{0}\right)}=$ weighted sum of values; $Z\left(S_{i}\right)=$ the measured value at the ith location; $\lambda_{i}=$ an unknown weight for the measured value at the ith location; $s_{0}=$ the prediction location; $\mathrm{N}=$ the number of measured values.

In the kriging technique, the weights (represented by $\lambda_{i}$ ) are based on both the distance between the measured points and the prediction location and also the overall spatial arrangement of the measured points. To use the spatial arrangement in the weights, the spatial autocorrelation must be quantified. 
In the ordinary kriging, the weight, $\lambda_{i}$ depends on a fitted model to the measured points, the distance to the prediction location, and the spatial relationships among the measured values around the prediction location. The following section briefly discusses how the ordinary kriging formula is used to create a map of the prediction surface and a map of the accuracy of the predictions.

There are a number of kriging techniques discussed in the literature. However, to avoid cumbersome discussion, we would only adopt ordinary kriging in this study. Ordinary kriging estimates the unknown value using weighted linear combinations of the available sample (Isaaks and Srivastava, 1989):

$$
\hat{v}=\sum_{j=1}^{n} w_{j} * v \sum_{i=1}^{n} w_{i}=1
$$

The error of $i$ th estimate, $r_{i}$, is the difference of estimated value and true value at that same location:

$$
r_{i}=\hat{v}-v_{i}
$$

The average error of a set of $\mathrm{k}$ estimates is:

$$
m_{\tau}=\frac{1}{k} \sum_{i=1}^{k} r_{i}=\frac{1}{k} \sum_{i=1}^{k} \hat{v}_{i}-v_{i}
$$

The error variance is:

$$
\delta_{R}^{2}=\frac{1}{k} \sum_{i=1}^{k}\left(r_{i}-m_{R}\right)^{2}=\frac{1}{k} \sum_{i=1}^{k}\left[\hat{v}_{i}-v_{i}-\frac{1}{k} \sum_{i=1}^{k}\left(\hat{v}_{i}-v_{i}\right)\right]^{2}
$$

However, we cannot use the equation because we do not know the true value $\mathrm{V}_{1}, \ldots, \mathrm{V}_{\mathrm{k}}$. In order to solve this problem, we apply a stationary random function that consists of several random variables, $V\left(x_{i}\right) . \mathrm{X}_{\mathrm{i}}$ is the location of observed data for $\mathrm{i}>0$ and $\mathrm{i} \leqq \mathrm{n}$. ( $\mathrm{n}$ is the total number of observed data). The unknown value at the location $\mathrm{X}_{0}$ we are trying to estimate is $\widetilde{\widetilde{V}}\left(x_{0}\right)$. The estimated value represented by random function is:

$$
\begin{aligned}
\widetilde{V}\left(x_{0}\right) & =\sum_{i=1}^{n} w_{i} * V\left(x_{i}\right) \\
R\left(x_{0}\right) & =\widetilde{V}\left(x_{0}\right)-V\left(x_{0}\right)
\end{aligned}
$$

The error variance is:

$$
\widetilde{\delta}_{R}^{2}=\widetilde{\delta}^{2}+\sum_{i=1}^{n} \sum_{j=1}^{n} w_{i} w_{j} \widetilde{C}_{i j}-2 \sum_{i=1}^{n} w_{i} \widetilde{C}_{i 0}+2 \mu\left(\sum_{i=1}^{n} w_{i}-1\right)
$$

$\widetilde{\delta}^{2}$ is the covariance of the random variable $\mathrm{V}_{(\mathrm{X} 0)}$ with itself and we assume that all of our random variables have the same variance while $\mu$ is the Lagrange parameter.

In order to get the minimum variance of error, we calculate the partial first derivatives of the equation (11) for each $w$ and setting the result to 0 . The example of differentiation with respect to $w$ is:

$$
\frac{\delta\left(\widetilde{\sigma}_{R}^{2}\right)}{\delta w_{1}}=2 \sum_{j=1}^{n} w_{j} \widetilde{C}_{1 j}-2 \widetilde{C}_{10}+2 \mu=0 \quad \sum_{j=1}^{n} w_{j} \widetilde{C}_{1 j}+\mu=\widetilde{C}_{10}
$$

All of weight $\mathrm{w}_{\mathrm{i}}$ can be represented as:

$$
\sum_{j=1}^{n} w_{i} \widetilde{C}_{i j}+\mu=\widetilde{C}_{i 0}
$$


For each $\mathrm{i}, 1 \leq \mathrm{i} \leq \mathrm{n}$

We can get each weight $\mathrm{W}_{\mathrm{i}}$ through equation (13). After getting the value, we can estimate the value located in $\mathrm{X}_{0}$. We can use variogram instead of covariance to calculate each weight of equation (12). The variogram and minimized estimation variance are:

$$
\begin{gathered}
\gamma_{i j}=\widetilde{\delta}^{2}-\widetilde{C}_{i j} \\
\widetilde{\delta}_{R}^{2}=\sum_{i=1}^{n} w_{i} \gamma_{i 0}+\mu
\end{gathered}
$$

The kriging module includes two variogram models:

Spherical

Exponential

$$
\tilde{\gamma}(h)= \begin{cases}C+C\left(1.5 \frac{h}{a}-0.5\left(\frac{h}{a}\right)\right)^{3} & \text { if }|h| \leq a \\ C_{0}+C_{1} & \text { if }|h|>a\end{cases}
$$

$$
\tilde{\gamma}(h)= \begin{cases}0 & \text { if }|h|=a \\ C_{0}+C_{1}\left(1-\exp \left(\frac{-3|h|}{a}\right)\right) & \text { if }|h|>a\end{cases}
$$

Nugget effect ( $\left.\mathbf{c}_{\mathbf{0}}\right)$

Though the value of the variogram for $\mathrm{h}=0$ is strictly 0 , several factors, such as sampling error and short scale variability, may cause sample values separated by extremely small distances to be quite dissimilar. This causes a discontinuity at the origin of the variogram. The vertical jump from the value of 0 at the origin to the value of the variogram at extremely small separation distances is called the nugget effect (Isaaks and Srivastava, 1989). Range (a)

As the distance of two pairs increases, the variogram of those two pairs also increases. Eventually, the increase of the distance cannot cause the variogram to increase. The distance which causes the variogram to reach plateau is called range (see Figure 1).

Sill $\left(\mathbf{C}_{\mathbf{0}}+\mathbf{C}_{\mathbf{1}}\right)$

It is the maximum variogram value which is the height of plateau (see Figure 1).

Distance $\mathbf{h}$

It is the distance between estimated location and observed location.

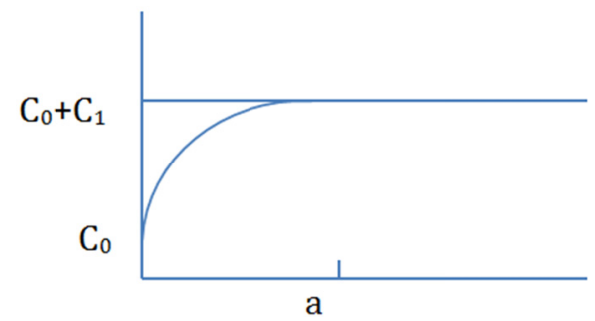

Figure 1. An Example of Exponential Variogram Model

Equation (16) can be written in matrix notation as $\mathbf{V} * \mathbf{W}=\mathbf{D}$ where $\mathrm{V}$ is $(\mathrm{n}+1) \mathrm{x}(\mathrm{n}+1)$ matrix which contains the variogram of each known data. The components of last column and row are 1 and the last component of the matrix is $0 ; \mathrm{W}$ is $(\mathrm{n}+1)$ matrix which contains the weight corresponding to each location. the last of component 
of matrix is Lagrange parameter; and $\mathrm{D}$ is $(\mathrm{n}+1)$ matrix which contains the variogram of known data and estimated data. The last component of the matrix is 1 .

Since $\mathrm{V}$ and $\mathrm{D}$ is known, we can get the unknown matrix $\mathrm{W}$ by $\mathbf{W}=\operatorname{invert}(\mathbf{V}) * \mathbf{D}$. Applying equation (13), we can get the estimated value on a specific location. We also can get the error variance from the square root of equation (17).

\section{Methodology}

A sample-based flood damage survey was conducted in early 2015 in Kuaka Krai and Dabong. This study area was chosen because it was the most severely-hit sub-region of the state of Kelantan. Furthermore, state-wide FD-RAM was not possible due to data and financial limitations. Sample-based field inspections were conducted to estimate flood damage to buildings, trees, and other items. Since it was very difficult to account for each item damaged by flood, this study was confined only to estimating damages of residential and agricultural properties. Some moveable assets categorised as "contents" (e.g. furniture, house appliance, equipment), were, however, accounted for. As many as 336 geo-referenced sites (longitude and latitude in metres) within the flood inundated river corridors were sampled and mapped as "survey points" shape file (see Figure 2).

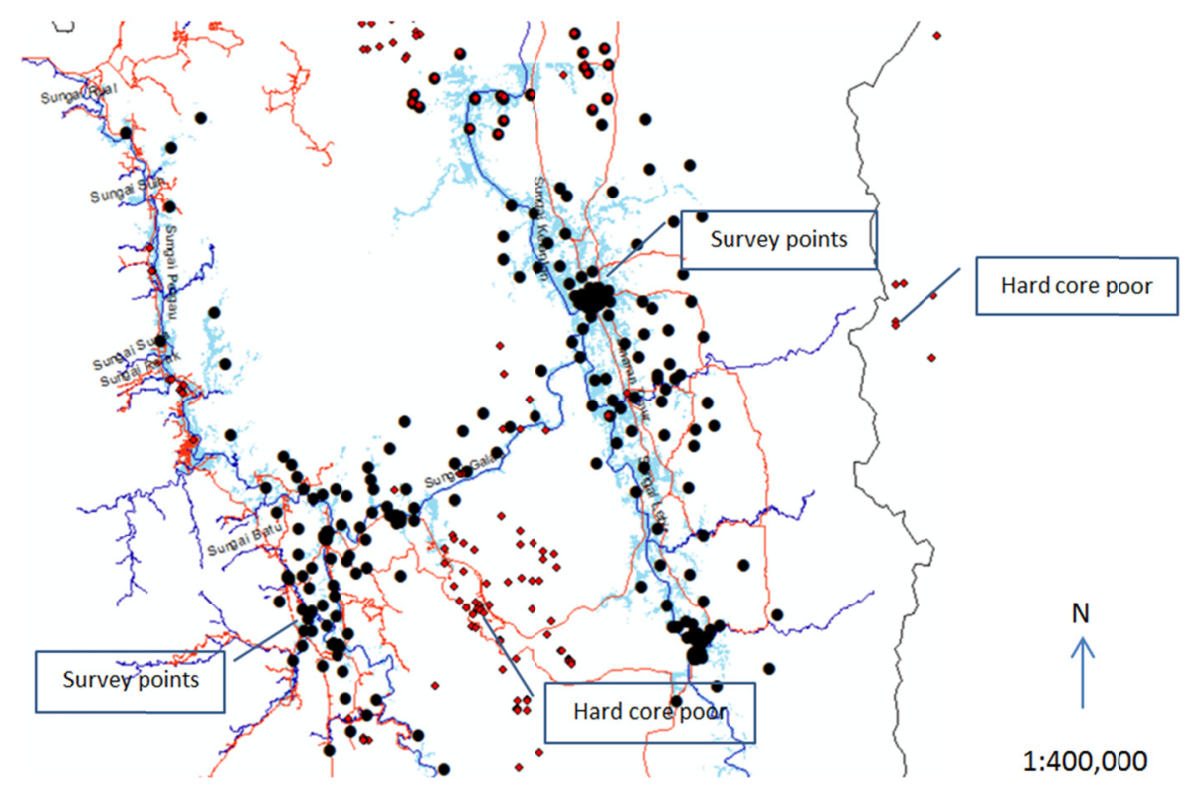

Figure 2. Survey points shape file in the selected study area. These survey points include locations of some hard core poor's homes (smaller dots)

Data on flood-related factors were collected at each sampled location, namely land value (asking price) (RM/acre); building value (replacement cost new) (RM/unit); proportion of structural damage (\%); proportion of content damage (\%); current use (forest, agriculture, natural vegetation, urban, transport, built-up); use activity (rubber, oil palm, orchard, water body, road, vacant, residential); structural type (soil, building); content type (tree, building, miscellaneous items); and flood depth (feet). All of the information was formatted as attribute table of the "survey points" shape file in ArcGIS software. The purpose of this shape file was to enable spatial modelling of flood damage using Geographically Weighted Regression (GWR) technique based on the following specification:

TotDmg $=\mathrm{f}($ Curuse, Activ, Structy, Contyp, Flo_dep)

where TotDmg $=$ Total flood damage $(\mathrm{RM}) ;$ Curuse $=$ Current use; Acti $=$ Use activity; Structy = Structural type; Contyp = Content type; and Floo_dep = Flood depth (feet).

Damage estimation according to of property type is given as in equations (1) and (2) above. Spatially assessed flood damage by kriging technique was used in performing data analysis.. Flood damage was calculated as follows:

TotDmg $=$ ContDmg1 + ContDmg2 + StrDmg1 + StrDmg2

where ContDmg1 = CD_P x Buildv x ef; ContDmg2 $=$ CD_P x Landv x ef; StrDmg1=SD_P x Buildv x ef; StrDmg2 $=$ SD_P $\times$ Landv $\times$ ef. $[\mathrm{ef}=1 \mathrm{IF}$ sampled point $=$ Residential/building; ef $=0 \mathrm{IF}$ sampled point $=$ 
Agriculture/forest]

where CD_P $=\%$ of content damage; SD_P $=\%$ of structural damage; Landv = land value (RM/unit); and Buildv $=$ building value $(\mathrm{RM} / \mathrm{unit})$.

In the damage assessment process, the following guide was used:

$$
\begin{gathered}
\text { ContDmg1 = content damage for residential/building } \\
\text { ContDmg2 = content damage for agricultural crop/forest } \\
\text { StrDmg1 = structural damage for Residential/building } \\
\text { StrDmg2 = structural damage for agricultural crop/forest }
\end{gathered}
$$

Building value was estimated based on replacement cost new (RCN) of the original building. This was a challenging process since RCN cannot easily and accurately be estimated. Although the ideal method was to base value estimates on official government valuation, this was not possible due to resource constraints. The regression procedure for the above specification followed the steps as outlined in equations (4) through (17). GWR was run to relate flood damage (content $\&$ structural) with their influencing factors, namely current land use (Curuse), land use activity (Activ), property structural type (Structy), and flood depth (Flo_dep).

Once outputs were generated, superimposition process was performed whereby land use map was overlaid on modelled flood, and GWR-kriged flood damage estimate. A manual process of identifying, listing, and estimating damages of various types of properties was carried out using this superimposed map. (See example in Figure 3.)

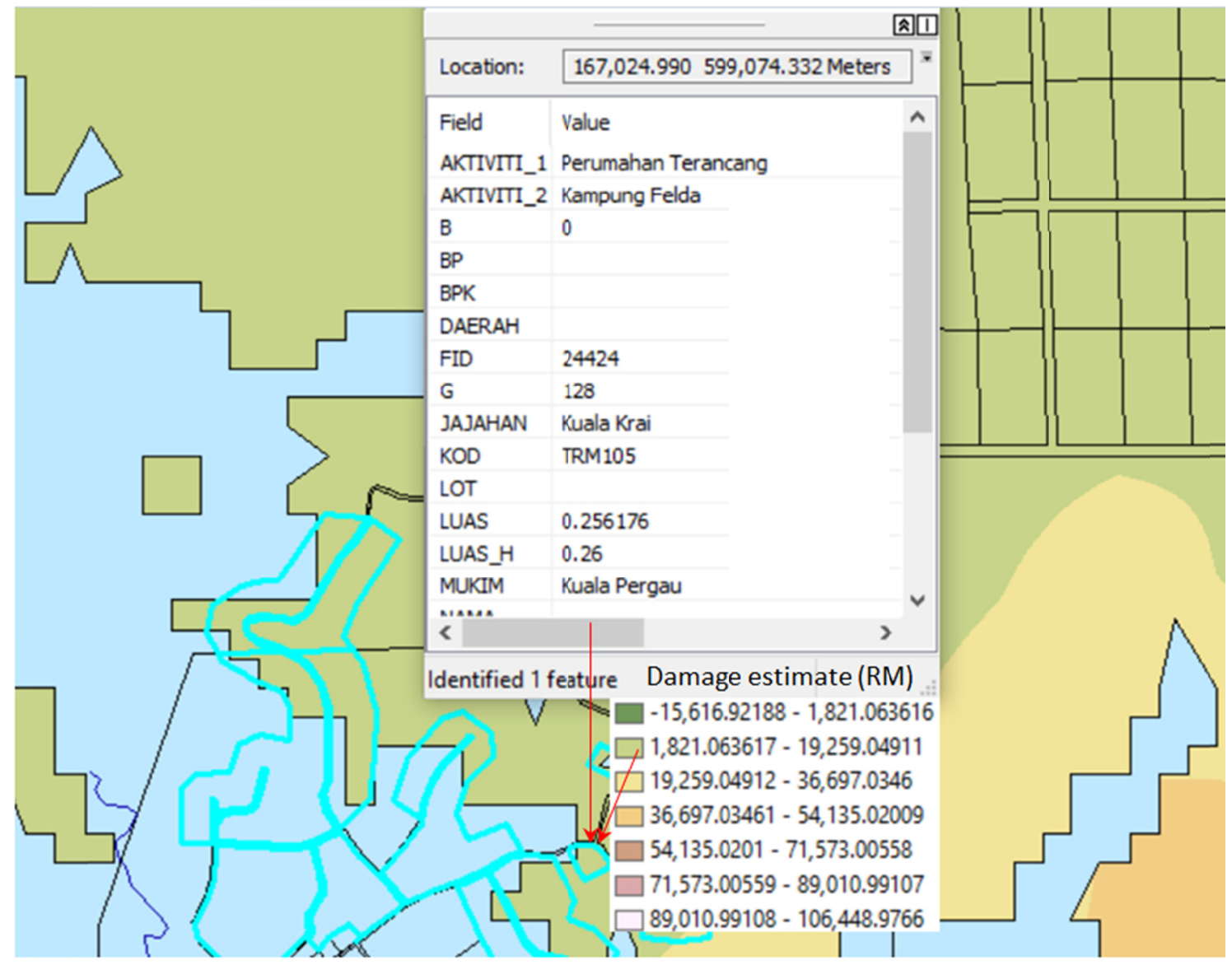

Figure 3. Screen shot of an overly of land use, modelled flood, and GWR-kriged flood damage estimate

\section{Results and Discussion}

Figure 4 shows flood hazard superimposed on GWR-kriged flood damage map over the study area. 


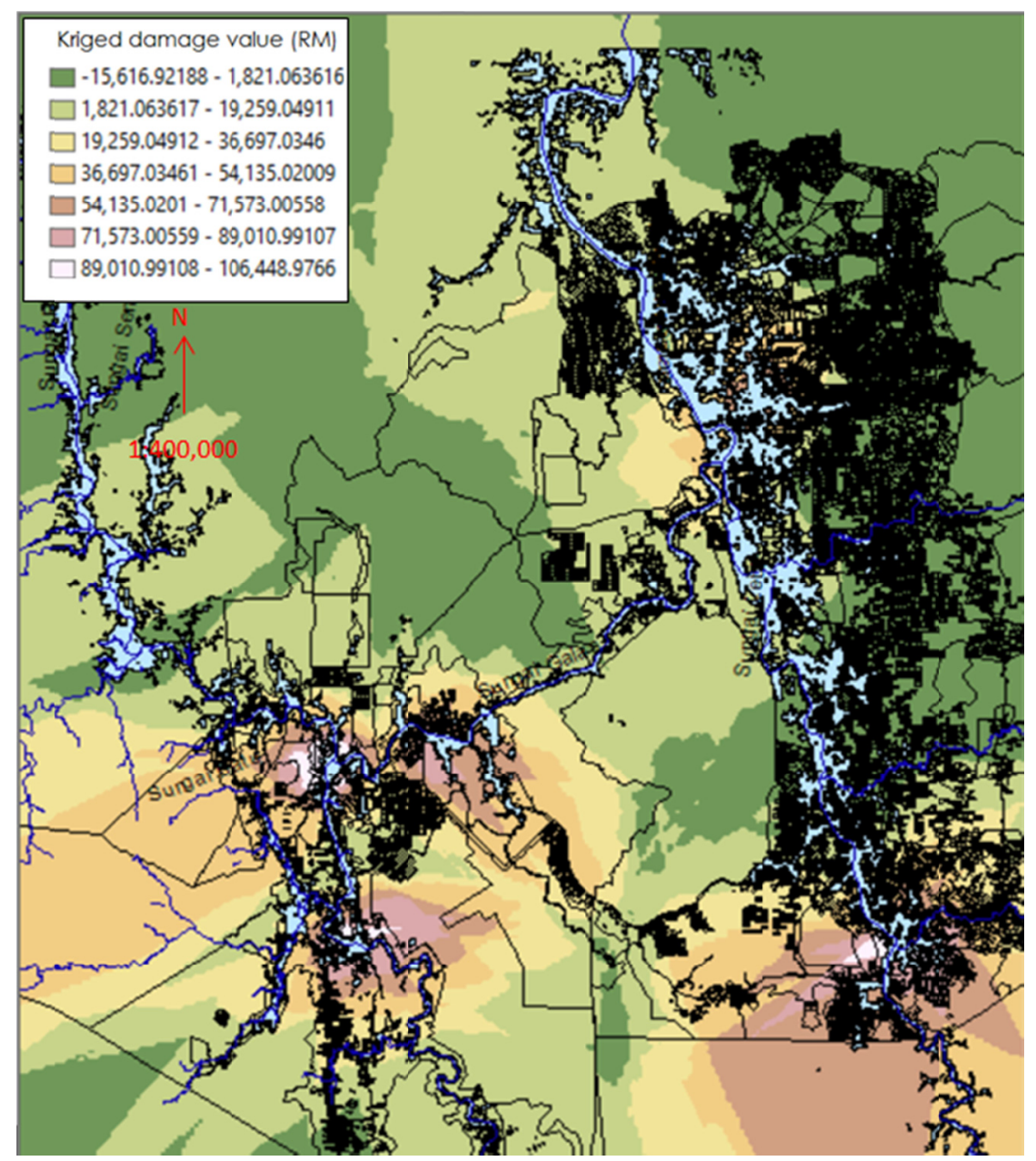

Figure 4. Flood hazard superimposed on GWR-kriged flood damage map

Flood damage and, thus, flood risk is higher in densely populated locations such as urban or residential areas. Besides, sites closer to river banks (say, less than $1 \mathrm{~km}$ ) were mostly exhibited greater flood depth. Other factors also contribute to the magnitude of damage.

The regression results are shown in Table 1 . The performance of the GWR was very modest with a local $R^{2}$ of only 0.58 . This reflects the shortcoming in modelling spatial relationship of flood damage since, apart from land use factors, many other hydrological and geomorphological factors were not included in the model specification due to data limitation.

From Table 1, flood depth was found to be significantly influencing flood damage. Content type was also significant to property damage while other land use factors did not show statistical significance. With respect to content type, miscellaneous contents of moveable property such as furniture and appliances could have incurred damage of RM 31,221 more than other types of contents such as trees and vegetation whenever there was flood inundation in the study area.

Table 1. General statistical results of Geographically Weighted Regression (GWR)

\begin{tabular}{lrr}
\hline VARNAME & VARIABLE & DEFINITION \\
\hline Bandwidth & $26,115.340592$ & \\
Residual Squares & $506,075,220,856.614$ & \\
Effective Number & 15.870035 & \\
Sigma & $3,9697.86226$ & \\
AICc & $8,105.709384$ &
\end{tabular}

Dependent: TotDmg Total flood damage (RM) 


\begin{tabular}{lrrrrrr}
\hline Local R & \\
$\mathrm{R}^{2}$ Adjusted & 0.58 & & & & & \\
Residual & 0.56 & & & & & \\
Standard Error & $1,480.77$ & & & & & \\
Std. Residual & $38,692.17$ & & & & & \\
Sample size & 0.03 & & & & & \\
& 336 & & & & & \\
& Coefficient & Std. error & t-value & Min & max & confidence \\
Intercept & $-26,585.93$ & $5,681.39$ & -4.68 & $-31,286.39$ & $-16,581.87$ & 332.69 \\
Current use (Curuse) & $24,545.44$ & $21,285.12$ & 1.15 & $18,093.14$ & $42,160.54$ & 574.24 \\
Activity (Acti) & $13,029.86$ & $17,976.61$ & 0.72 & $-4,936.35$ & $21,905.10$ & 523.05 \\
Structural type (Structy) & $8,150.71$ & $19,128.44$ & 0.43 & $-5,129.26$ & $32,765.70$ & $1,103.62$ \\
Content type (Contyp) & $31,221.04$ & $18,104.81$ & 1.72 & $15,234.98$ & $36,765.76$ & 396.62 \\
Flood depth (Floo_dep) & $5,547.52$ & 873.03 & 6.35 & $3,659.86$ & $6,808.20$ & 97.33 \\
\hline
\end{tabular}

By manually using the GIS map, various types of properties were identified and listed together with their corresponding damage (see Table 2). Many places were severely inundated, more than $70 \%$ in some cases.

Table 2. Flood inundation over some selected land uses in the study area - GIS analysis

\begin{tabular}{|c|c|c|c|c|c|c|c|}
\hline Land use & $\begin{array}{l}\text { Total area } \\
\text { (ha.) }\end{array}$ & $\begin{array}{l}\text { Total } \\
\text { inundated } \\
\text { area (ha.) }\end{array}$ & Approx & $\begin{array}{c}\text { Structural } \\
\text { Damage (\%) }\end{array}$ & $\begin{array}{c}\text { Content } \\
\text { Damage } \\
(\%)\end{array}$ & $\begin{array}{c}\text { Area } \\
\text { Affected } \\
\text { (structural) } \\
\text { (ha.) }\end{array}$ & $\begin{array}{c}\text { Area } \\
\text { Affected } \\
\text { (content) } \\
\text { (ha.) }\end{array}$ \\
\hline & & & $(\%)$ & & & & \\
\hline \multicolumn{8}{|l|}{ Kediaman: } \\
\hline Kampung Felda & 310.16 & 92.26 & 30 & 0 & 45 & 0.00 & 1.45 \\
\hline Kampung Setinggan & 0.67 & 0.18 & 27 & & & & \\
\hline Kampung Tersusun & 112.36 & 90.33 & 80 & 55 & 61 & 0.76 & 0.85 \\
\hline Kampung Tradisi & 147.21 & 128.23 & 87 & 70 & 72 & 6.00 & 6.18 \\
\hline Perumahan Strata & 0.03 & 0.03 & 100 & & & & \\
\hline Perumahan Bukan Strata & 56.89 & 43.01 & 76 & 80 & 94 & 1.00 & 1.17 \\
\hline Perumahan Kakitangan & 10.54 & 10.27 & 97 & & & & \\
\hline Perumahan Ladang/Estet & 42.11 & 11.52 & 27 & & & & \\
\hline \multicolumn{8}{|l|}{$\begin{array}{l}\text { Perniagaan dan } \\
\text { Perkhidmatan: }\end{array}$} \\
\hline Perniagaan Terancang & 31.71 & 20.91 & 66 & 50 & 60 & 0.02 & 0.02 \\
\hline Perniagaan Tidak Terancang & 30.26 & 22.17 & 73 & & & & \\
\hline \multicolumn{8}{|l|}{ Pertanian: } \\
\hline Getah & 74233.19 & 46415.61 & 63 & 30 & 7 & 5326.82 & 1242.92 \\
\hline Kelapa Sawit & 8825.22 & 5947.63 & 67 & 0 & 11 & 0.00 & 354.53 \\
\hline Padi & 373.67 & 172.03 & 46 & & & & \\
\hline Dusun & 5671.7 & 2795.32 & 49 & 63 & 90 & 3.71 & 5.30 \\
\hline $\begin{array}{l}\text { Tanah Terbiar (Pertanian tidak } \\
\text { diusahakan) }\end{array}$ & 746.82 & 643.37 & 86 & 0 & 5 & 0.00 & 0.39 \\
\hline \multicolumn{8}{|l|}{ Industri: } \\
\hline Industri Terancang & 94.44 & 66.68 & 71 & & & & \\
\hline
\end{tabular}




\begin{tabular}{|c|c|c|c|c|c|c|c|}
\hline Industri Tidak Terancang & 71.77 & 51.42 & 72 & & & & \\
\hline \multicolumn{8}{|l|}{ Infrastruktur dan Utiliti: } \\
\hline Bekalan Air & 8.38 & 7.1 & 85 & & & & \\
\hline Bekalan Elektrik & 352.68 & 270.79 & 77 & & & & \\
\hline Pengairan dan Perparitan & 12.4 & 6.87 & 55 & & & & \\
\hline Telekomunikasi & 2.06 & 1.11 & 54 & & & & \\
\hline \multicolumn{8}{|l|}{$\begin{array}{l}\text { Institusi dan Kemudahan } \\
\text { Masyarakat: }\end{array}$} \\
\hline \multicolumn{8}{|l|}{ a) Keagamaan } \\
\hline Masjid & 21.45 & 10.46 & 49 & & & & \\
\hline Surau & 2.6 & 1.31 & 50 & & & & \\
\hline Tokong & 0.36 & 0.36 & 100 & & & & \\
\hline Kuil & 0.27 & 0.16 & 59 & & & & \\
\hline \multicolumn{8}{|c|}{$\begin{array}{l}\text { b) Kegunaan Kerajaan/Badan } \\
\text { Berkanun: }\end{array}$} \\
\hline $\begin{array}{l}\text { Pejabat Kerajaan/Agensi } \\
\text { Kerajaan }\end{array}$ & 46.15 & 35 & 76 & 50 & 60 & 0.03 & 0.03 \\
\hline Badan Berkanun & 37.5 & 37.4 & 100 & 50 & 60 & 0.03 & 0.03 \\
\hline \multicolumn{8}{|l|}{ c) Keselamatan } \\
\hline Balai Polis & 5.02 & 5.02 & 100 & & & & \\
\hline Balai Bomba & 0.4 & 0.4 & 100 & & & & \\
\hline Pondok Polis & 4.71 & 3.89 & 83 & & & & \\
\hline Kem Tentera & 7.3 & 7.3 & 100 & & & & \\
\hline \multicolumn{8}{|l|}{ d) Kesihatan } \\
\hline Klinik Kesihatan & 9.07 & 9.07 & 100 & & & & \\
\hline Klinik Desa & 6.3 & 2.23 & 35 & 0 & 0 & 0.00 & 0.00 \\
\hline Hospital & 4.23 & 4.23 & 100 & & & & \\
\hline \multicolumn{8}{|l|}{ e) Pendidikan } \\
\hline Tadika & 4.82 & 2.02 & 42 & & & & \\
\hline Sekolah Rendah & 130.07 & 91.36 & 70 & 30 & 50 & & \\
\hline Sekolah Menengah & 55.8 & 49.24 & 88 & & & & \\
\hline Sekolah Agama & 13.76 & 9.31 & 68 & & & & \\
\hline Institut Latihan & 0.33 & - & & & & & \\
\hline \multicolumn{8}{|l|}{ f) Perkuburan } \\
\hline Islam & 46.3 & 34.75 & 75 & 60 & 65 & & \\
\hline Cina & 11.06 & 11.06 & 100 & & & & \\
\hline Hindu/Sikh & 0.58 & 0.58 & 100 & & & & \\
\hline \multicolumn{8}{|l|}{$\begin{array}{l}\text { g) Lain-lain Kemudahan } \\
\text { Masyarakat }\end{array}$} \\
\hline Balai Raya & 1.75 & 1.25 & 71 & & & & \\
\hline Dewan Serbaguna Awam & 0.79 & 0.26 & 33 & & & & \\
\hline
\end{tabular}




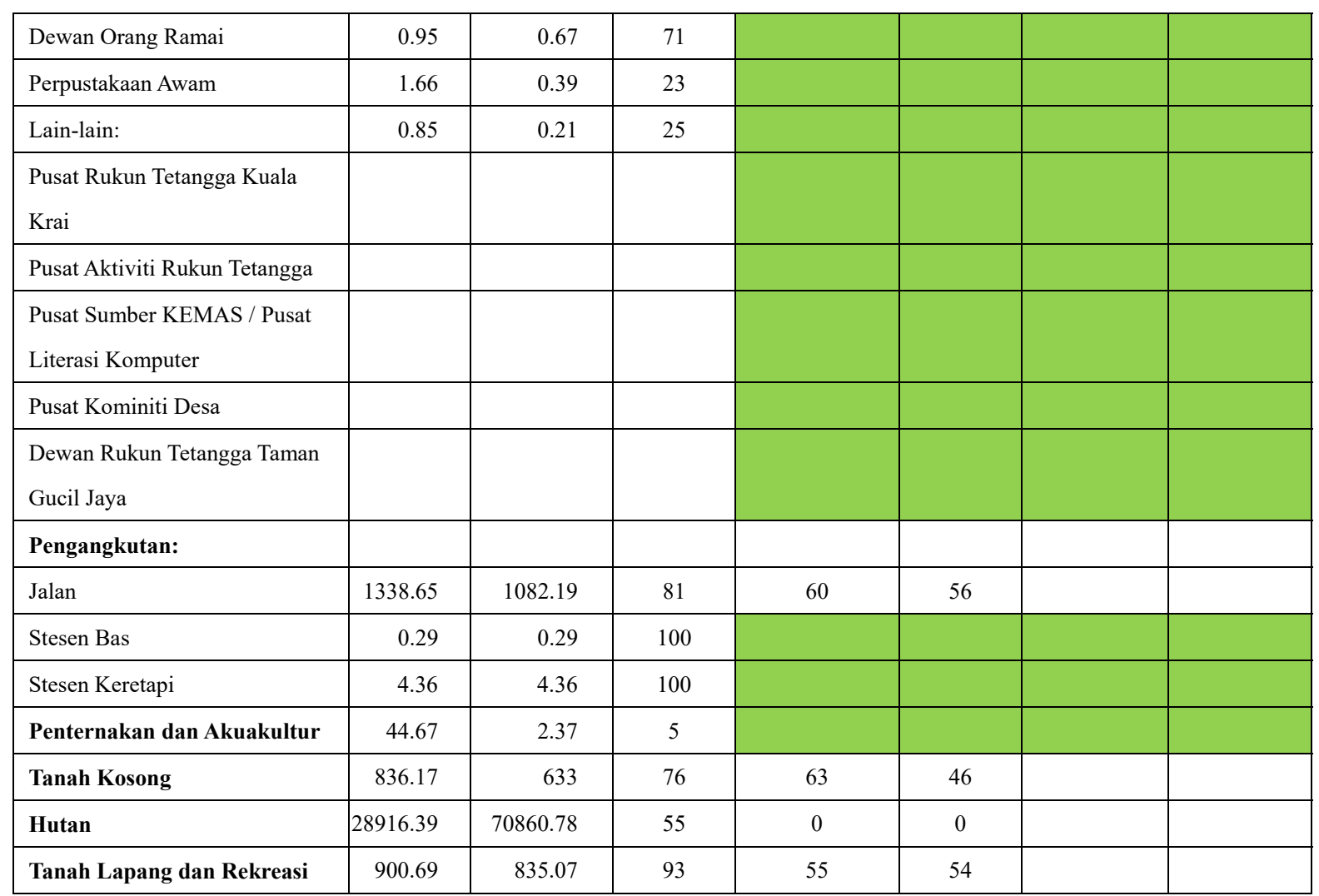

* Expressed as number of units rather than area of land (ha.)

No data were available on the map

To further illustrate the use of FD-RAM, Figure 5 took a group of hard core poor people as a case. The map indicates that the hard core poor group experienced low to severe flood damage. Most of them experienced a total flood damage of about RM 10,000/household. This a was quite small figure and was not surprising as many of them did not own high-value property. Nonetheless, this damage was about 26 times their monthly income and can be considered a huge suffering for a hard core poor family. The model, however, suffered from prediction inaccuracy and, thus, overstressing on damage figure may not be desirable due to possible over- or underestimation in the assessment process.

Not all of hard core poor in the study area were affected by flood and, thus, those hit must be identified. This was done by picking the affected hard core poor's homes from the map via clipping menu available in ArcGIS. In this case, modelled "flood polygon" layer was clipped onto "survey points" layer. The resulting clipped layer was then superimposed on another layer, namely kriged estimated total flood damage (ETFD). Figure 5 shows the locational distribution of hard core poor which was superimposed over kriged values of estimated total flood damage (ETFD) modelled using Geographically Weighted Regression based on equation (17). By this way, the hydrological and physical aspects of flood were factored into flood damage-estimating model. 


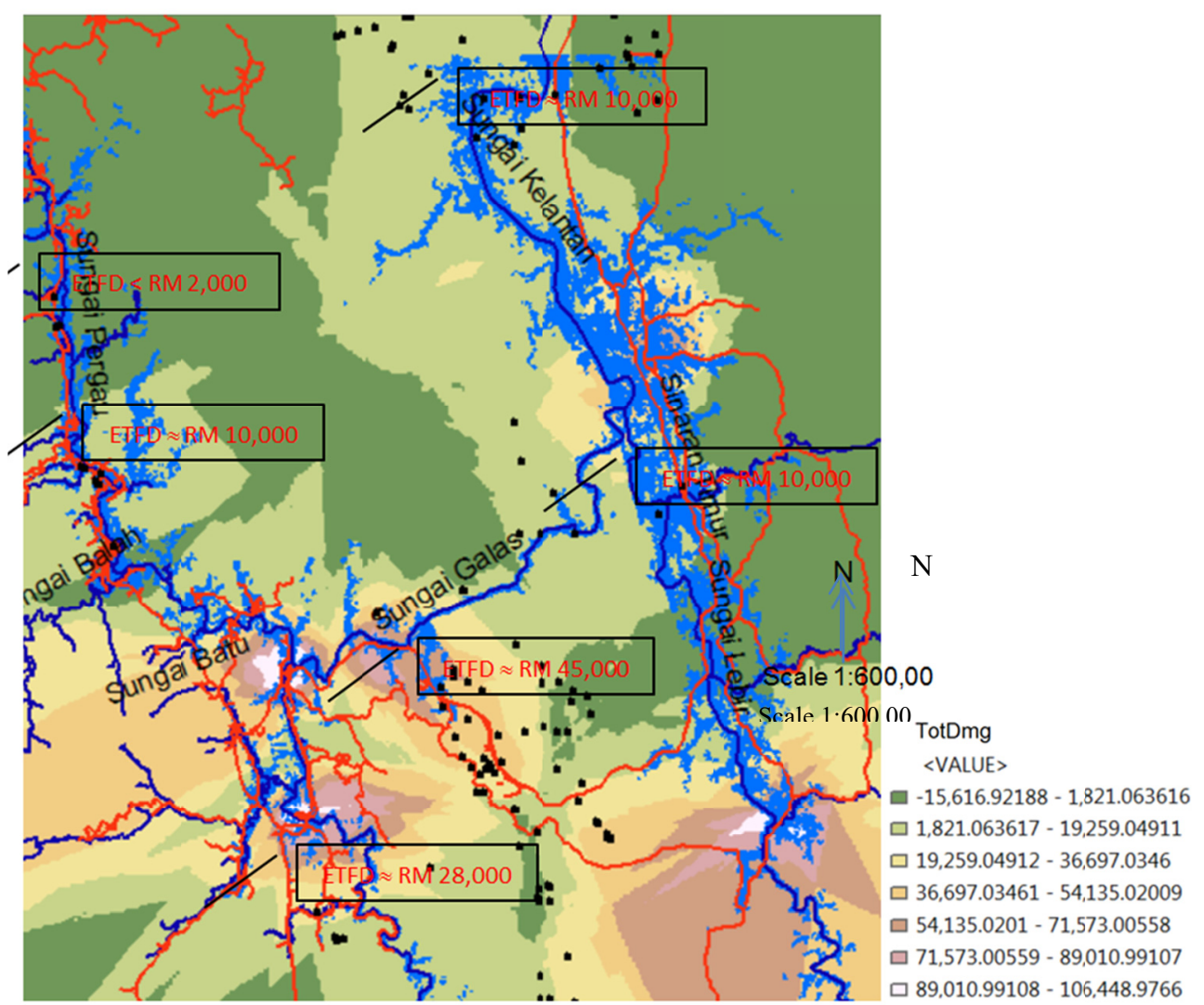

Figure 5. Kriged value of estimated total flood damage (ETFD) based on Geographically Weighted Regression among hard core poor (black dots) in the study area. Figures shown are middle-values of ETFD.
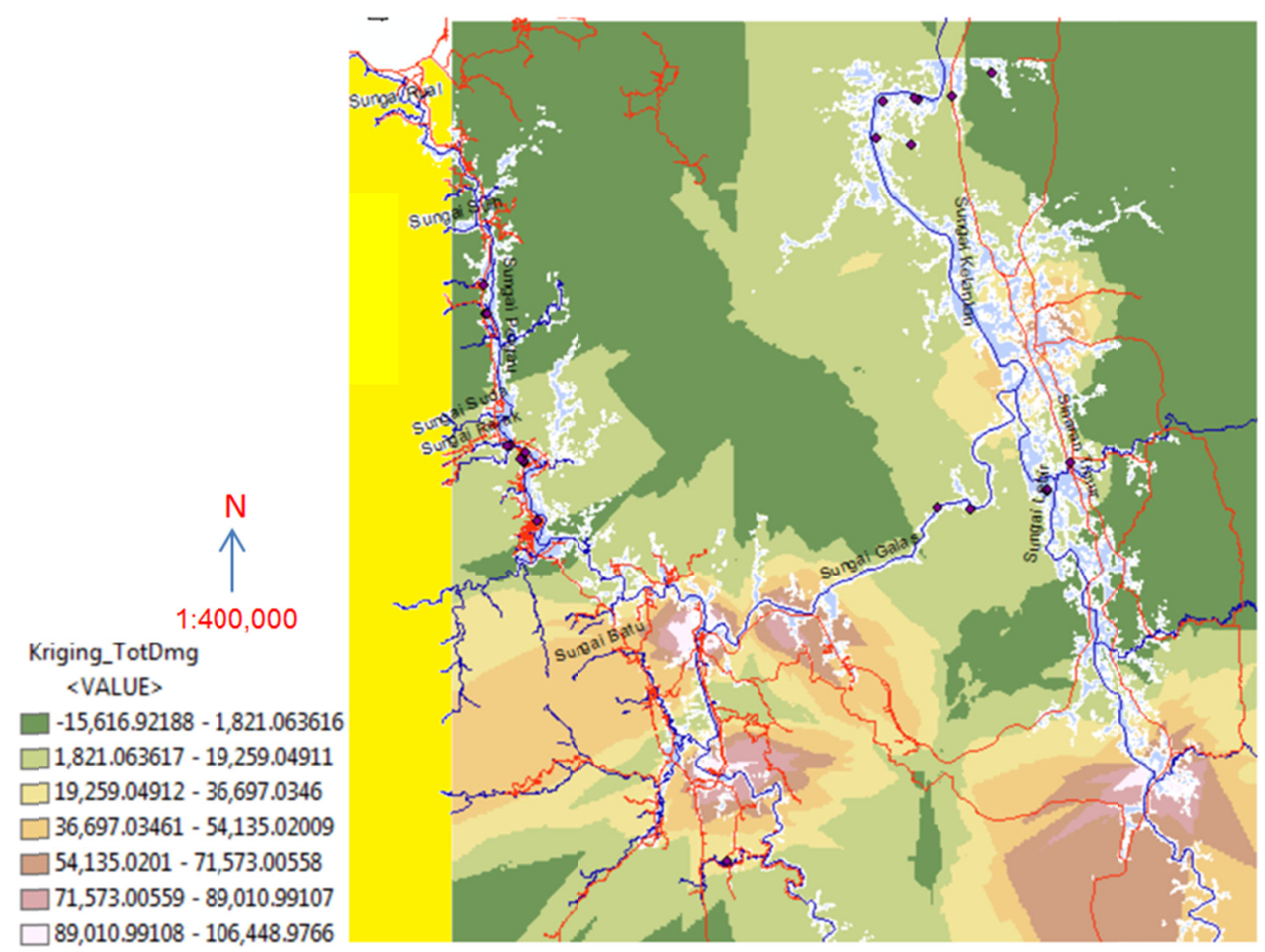

Figure 6. Identification of flood-hit hard core poor by ArcGIS procedure 
Table 3. Estimated total flood damage (ETFD) incurred by the hard core poor in the study area

\begin{tabular}{|c|c|c|c|c|c|c|c|}
\hline No & Name & Address & Lat & Long & District & Occupation & $\begin{array}{l}\text { ETFD } \\
(\mathrm{RM}) \\
\end{array}$ \\
\hline & JAHARAH BT & KG LALANG JENAL,KUALA & & & & & \\
\hline \multirow[t]{2}{*}{1.} & SALLEH & GRIS DAB 18200 & 5.2477 & 102.0250 & DABONG & 0 & 27,978 \\
\hline & MOHD RONI B & KG KUALA BALAH KUALA & & & KUALA & & \\
\hline \multirow[t]{2}{*}{2.} & ZAKARIA & BALAH 17610 & 5.4445 & 101.9145 & BALAH & 0 & 10,540 \\
\hline & MARILA BINTI & KG. AIR BELAGA, & & & & & \\
\hline \multirow[t]{2}{*}{3.} & ISMAIL & MACHNAG 18500 & 5.4524 & 102.1638 & ULU SAT & 0 & 10,540 \\
\hline & SALLAH BIN & KAMPUNG BUKIT TIU & & & & & \\
\hline \multirow[t]{3}{*}{4.} & DAUD & 18500 MACHANG 18500 & 5.4526 & 102.1447 & ULU SAT & 0 & 10,540 \\
\hline & RAHIMAH & & & & & & \\
\hline & BINTI & & & & & & \\
\hline \multirow[t]{2}{*}{5.} & SULAIMAN & KG. TELOSAN 16800 & 5.4632 & 102.2081 & JERAM & 0 & 10,540 \\
\hline & ZAKIAH BINTI & & & & & & \\
\hline \multirow[t]{2}{*}{6.} & DOLLAH & KG. TELOSAN 16800 & 5.4636 & 102.2083 & JERAM & 5 & 10,540 \\
\hline & MAJID & KG BUKIT JERING KUALA & & & KUALA & & \\
\hline \multirow[t]{3}{*}{7.} & DAUD & BALAH 17610 & 5.4780 & 101.9062 & BALAH & 4 & 10,540 \\
\hline & ZABIDAH & & & & & & \\
\hline & BINTI & KG. BUKIT JERING KUALA & & & KUALA & & \\
\hline \multirow[t]{2}{*}{8.} & IBRAHIM & BALAH 17610 & 5.4787 & 101.9064 & BALAH & 4 & 10,540 \\
\hline & ABDUL MALIK & & & & & & \\
\hline \multirow[t]{2}{*}{9.} & BIN ISMAIL & KG. JERAM 16800 & 5.4791 & 102.2211 & JERAM & 0 & 10,540 \\
\hline & MUHAMMAD & KG. BKT JERING KUALA & & & KUALA & & \\
\hline \multirow[t]{3}{*}{10.} & BIN ALI & BALAH 17610 & 5.4800 & 101.9048 & BALAH & 1 & 10,540 \\
\hline & HALIMAH & & & & & & \\
\hline & BINTI & KG. JERIMBONG KUALA & & & KUALA & & \\
\hline \multirow[t]{2}{*}{11.} & MOHAMAD & BALAH 17610 & 5.4835 & 101.9075 & BALAH & 1 & 10,540 \\
\hline & MA KALSOM & KG. BUKIT SELAR KUALA & & & KUALA & & \\
\hline \multirow[t]{2}{*}{12.} & BINTI OMAR & BALAH 17610 & 5.4871 & 101.8987 & BALAH & 1 & 10,540 \\
\hline & HASLI BIN & KG. RELAK KUALA BALAH & & & KUALA & & \\
\hline \multirow[t]{3}{*}{13.} & IBRAHIM & 17610 & 5.4876 & 101.8970 & BALAH & 4 & 10,540 \\
\hline & MOHD ABU & NO.117, $\quad$ KG. $\quad$ LUBOK & & & & & \\
\hline & BAKAR BIN & BONGOR KUALA BALAH & & & KUALA & & \\
\hline \multirow[t]{3}{*}{14.} & MAT JIDIN & 17610 & 5.5635 & 101.8837 & BALAH & 0 & 2,000 \\
\hline & & NO. $134, \quad$ KG. $\quad$ LUBOK & & & & & \\
\hline & YAAKUB BIN & BONGOR KUALA BALAH & & & KUALA & & \\
\hline \multirow[t]{2}{*}{15.} & MAT MIN & 17610 & 5.5640 & 101.8848 & BALAH & 4 & 2,000 \\
\hline & MAT YAAKOB & KG SG RENYUK KUALA & & & KUALA & & \\
\hline \multirow[t]{2}{*}{16.} & BIN SALLEH & BALAH 17610 & 5.5799 & 101.8827 & BALAH & 0 & 2,000 \\
\hline & MOHAMAD & & & & & & \\
\hline \multirow[t]{3}{*}{17.} & BIN SAHAK & LEPAN PERINGAT 18400 & 5.6628 & 102.1289 & TEMANGAN & 3 & 10,540 \\
\hline & MEK NABLOH & & & & & & \\
\hline & BINTI & & & & & & \\
\hline \multirow[t]{2}{*}{18.} & ABDULLAH & KAMPUNG KERILLA 18500 & 5.6664 & 102.1090 & TEMANGAN & 0 & 10,540 \\
\hline & NAZMIAH BT & KG. PASIR SENOR & & & & & \\
\hline \multirow[t]{3}{*}{19.} & HARON & TEMANGAN 18400 & 5.6874 & 102.1127 & TEMANGAN & 0 & 10,540 \\
\hline & ABDULLAH & & & & & & \\
\hline & BIN AWANG & TEMANGAN & & & & & \\
\hline 20. & HAMAT & LAMA 18400 & 5.6878 & 102.1322 & TEMANGAN & 0 & 10,540 \\
\hline & ZAINI BIN CHE & & & & & & \\
\hline 21. & THE & KG KERILLA 18500 & 5.6891 & 102.1305 & TEMANGAN & 0 & 10,540 \\
\hline & FATIMAH & KAMPUNG & & & & & \\
\hline 22. & BINTI HASSAN & TEMANGAN 18400 & 5.6902 & 102.1522 & TEMANGAN & 0 & 10,540 \\
\hline
\end{tabular}

Note: Some of data columns were removed to save space 


\section{Conclusion}

Although accurate estimate was not the focus of this study, being able to derive some initial figure of flood damage is an important aspect of emergency relief and recovery program by the authority. The ability of knowing the 'possible' amount of damage at a specific site is an additional useful piece of information to the government.

The usefulness of rapid damage assessment of flood disaster largely depends on the completeness of data and accuracy of damage-estimating model. The correct GWR model specification that will result in satisfactory results was rather difficult and the available body of literature was not that useful to identify all the correct variables to include. Trial and error specification and test of the candidate variables such as those of geomorphological, hydrological, physical demanded a lot of data collection that was not possible due to resource constraint.

Accurate identification of 'itemised objects' affected by flood is always a problem of flood damage estimation. In this study, only content and structural damage of certain types of property/asset were quite conveniently accounted for their respective owners their respective owners their respective owners. Moveable assets such as vehicle, machinery, agricultural tools, etc. were not easily taken into account for various technical reasons. Assignment of damages of crops and animals to their respective owners was also difficult especially for those whose properties/assets were located on different sites away from their living premise.

Estimating flood damage was very challenging particularly in choosing the most appropriate approach of valuation. Cost, market and investment approaches are legitimate bases of asset valuation but none can be suitable for all situations and for all property types. Detailed examination of the property is thus necessary before deciding on the appropriate approach to valuation. This was simply not possible in rapid damage assessment procedure.

\section{References}

Abd, J. H., \& Aminuddin, A. G. (2006). Development of flood risk map using GIS for Sg. Selangor Basin. Retrieved from http://www.redac.eng.usm.my.html

Azura, A. (2015). RM78mil to clean post-flood Kelantan. New Straits Times, 7(January).

Fotheringham, A. S., Brunsdon, C., \& Charlton, M. (2002). Geographically Weighted Regression the Analysis of Spatially Varying Relationship. John Wiley \& Sons, LTD.

Fotheringham, A. S., Brunsdon, C., \& Charlton, M. (2005). Geographically Weighted Regression. ESRC National Centre for Research Methods, June, University of Leeds.

Fotheringham, A. S., Brunsdon, C., \& Charlton, M. E. (2000). Quantitative Geography, London: Sage.

Green, C. H., Viavattene, C., \& Thompson, P. (2011). Guidance for Assessing Food Losses. CONHAZ Report, Flood Hazard Research Centre - Middlesex University, Middlesex, WP6 Report.

Isaaks, E. H., \& Srivastava, R. H. (1989). An Introduction to Applied Geostatistics.

Malczewski, J. (1997) Spatial Decision Support Systems, NCGIA Core Curriculum in GIScience. Retrieved from http://www.ncgia.ucsb.edu/giscc/units/u127/u127.html

Merz, B., Kreibich, H., Schwarze, R., \& Thieken, A. (2010). Assessment of Economic Flood Damage. Natural Hazards and Earth System Science, 10, 1697-1724.

Messner, F., PennningRowsell, E. C., Green, C., Meyer, V., Tunstall, S. M., \& van der Veen, A. (2007). Evaluating flood damages: Guidance and recommendations on principles and methods, FLOODsite, Wallingford, UK, T09-06-01.

Poser, K., \& Dransch, D. (2010). Volunteered Geographic Information for Disaster Management with Application to Rapid Flood Damage Estimation. Geomatica, 64(1), 89-98.

Pradhan, B. (2009). Flood Susceptible mapping and risk area delineation using logistic regression, GIS and remote sensing. Journal of Spatial Hydrology, 9(2), 1-18.

Thieken, A. H., Muller, M., Kreibich, H., \& Merz, B. (2005). Flood damage and influencing factors: New insights from the August 2002 flood in Germany. Water Resources Research, 41(12), W12430+.

Thieken, A. H., Olschewski, A., Kreibich, H., Kobsch, S., \& Merz, B. (2008). Development and evaluation of FLEMOps a new Flood Loss Estimation Model for the private sector. In D. Proverbs, C. A. Brebbia, and E. Penning-Rowsell, editors, Flood Recovery, Innovation and Response I. 


\section{Copyrights}

Copyright for this article is retained by the author(s), with first publication rights granted to the journal.

This is an open-access article distributed under the terms and conditions of the Creative Commons Attribution license (http://creativecommons.org/licenses/by/4.0/). 